\title{
Organizational Culture, Employee Motivation, Workload and Employee Performance: A Mediating Role of Communication
}

\author{
MAHDANI IBRAHIM ${ }^{1}$, JUMADIL SAPUTRA ${ }^{2}$, MUHAMMAD ADAM $^{1}$, MUKHLIS YUNUS $^{1}$ \\ ${ }^{1}$ Department of Management, Faculty of Economics and Business, \\ Universitas Syiah Kuala, Darussalam, Banda Aceh, Aceh, \\ INDONESIA
}

\author{
${ }^{2}$ Department of Economics, Faculty of Business, Economics and Social Development, \\ Universiti Malaysia Terengganu, 21030 Kuala Nerus, Terengganu, \\ MALAYSIA
}

\begin{abstract}
This study investigates the mediating role of communication in the relationship between organizational culture, employee motivation, and workload on employee performance in Batam Port Management Partnership and Business Development Section, Indonesia. The study used a quantitative approach involving 50 Batam ports, Indonesia. A total of 150 respondents participated in this study and were collected by distributing the questionnaire. The data were analyzed with structural equation modelling - partial least square (SEM-PLS). The result of this study indicated that organizational culture and communication have a significant positive relationship with employee performance. Besides that, motivation and workload do not significantly affect employee performance. Also, communication mediates the relationship between workload and employee performance. In conclusion, the present study proved that communication is a significant factor in determining employee performance and plays a significant role as mediating variable between workload and employee performance. This study contributes significantly to the theory and government policy regarding human resource development. In addition, this study can assist the Batam port in increasing employee performance through communication.
\end{abstract}

Key-Words: Organizational Culture, Employee Motivation, Workload, Communication, Performance Received: June 11, 2021. Revised: December 17, 2021. Accepted: January 3, 2022. Published: January 4, 2022.

\section{Introduction}

Human resource plays a crucial role in the organization. Human resource needs special attention, management, handling, and treatment due to their role in implementing the policies and company operational activities to achieve the organization's target. Human resource management is planning, coordinating, implementing, and supervising procurement, development, remuneration, integration, maintenance, and separation of labour to achieve organizational goals.

Batam port is an operator in the free trade area.

It is in line with a joint decree of Transportation and the Head of the Batam Free Trade and Port Management Agency Number: KP 994 of 2017 and Number: 1456/SPJ/KA/11/2017, managed by the Batam Authority (Batam Concession Agency). The role aims to achieve the goal of making Batam one of the locomotives of national development. The legal principle for the operation of Batam port is attached to one of the main tasks of the Batam Authority (BP Batam), which Presidential Decree mandates No. 41 of 1973, which chronologically described as follows:

In 1971, the Central Government designated the island of Batam as a private industrial area with Presidential Decree No. 74 of 1971 to facilitate Pertamina's activities, logistical bases, and operations. With the government's strong commitment to developing Batam island as an industrial and trading area, the Presidential Decree No. 41 of 1973 was last amended to No. 113 of 2000. The president mandated 5 (five) main tasks to the Batam authority: (i) to plan, develop and control the development of Batam Island as an industrial area. (ii) Transhipment activities on the island of Batam. (iii) The need for infrastructure and operation of infrastructure installations. (iv) Examining applications for business licenses and submitting them to the relevant agencies, and (v) Ensuring that licensing procedures run smoothly to foster investment interest.

The vision of the Batam Port Management Agency is to make the Batam region the leading economic area of the Asia Pacific and a major contributor to national economic development. At 
the same time, the mission of the Batam Port Management Agency is to realize Batam Island as an export-oriented green industrial area and realize Batam Island as a superior marine tourism area and international trade transhipment. The current study investigates the mediating role of employee communication in the relationship between organizational culture, employee motivation, and the workload on employee performance in Batam Port Management Partnership and Business Development Section, Indonesia.

\section{Literature Review}

\subsection{Organizational Culture}

Culture is an attitude, norms, values and ways of thinking humans learn throughout their lives[1]. Also, culture is a set of shared meanings and values that state a common form of life, and there are as many cultures as the number of meanings and values [2]. The organization is used as a place where the people work together in a rational, systematic, planned, organized, guided, and controlled in utilizing the resources (money, materials, machines, methods and the environment), infrastructure, data and others that are used efficiently and effectively to achieve organizational goals [3].

The organization is a system of roles, the flow of activities and processes (work relationship patterns) and involves several people as executors of tasks designed to achieve common goals [4]. Also, Chia [5] stated that an organization is a consciously coordinated social entity consisting of two or more people with relatively identifiable boundaries, which function in an ongoing manner to achieve a common set of goals.

Therefore, Lok \& Crawford [6] stated that organizational culture is "a term used to contain a series of behavioural variables. It refers to values, beliefs, and main principles that act as a basis for an organizational management system [7], [8]. At the organizational level, organizational culture is the assumptions, beliefs, values, and perceptions shared by organizational members that shape and influence attitudes, behaviour, and instructions for solving problems [9], [10].

According to Lok \& Crawford [6] and Tesluk, Farr \& Klein [9], indicators of organizational culture consist of (i) innovation, and risk-taking means that an innovative attitude and the courage to take risks must exist within the organization. (ii) Attention to detail means that the organization must pay attention to all provisions, analyze, and pay more attention to things. (iii) Result orientation focuses on results or income rather than the techniques and processes used to achieve these results. (iv) Individual orientation is defined as considering the effect of results on employees in the organization. (v) Team orientation is the ability to work in a team. (vi) Aggressiveness that individuals or people within the organization have a competitive nature, and (vii) Stability means that organizational activities are emphasized to maintain the status to continue to grow and develop.

\subsection{Motivation}

According to AbdiMohamud, Ibrahim \& Hussein [11], motivation is the key to a successful organization to maintain work continuity in the organization in a strong way and help to survive. Motivation is to provide appropriate guidance or direction, resources, and rewards to inspire an interest in working in the desired way. Motivation is a factor that encourages a person to do a certain activity. Therefore motivation is often interpreted as a driving factor in one's behaviour [12]. According to Urošević, Milijić, Đorđević-Maljković \& Karabašević [13], stated that indicators of employee motivation are: (i) Responsibility - Have high personal responsibility for their work, (ii) Job performance - Doing something/work as well as possible, (iii) Opportunities for advancement - The desire to get a fair wage according to work, (iv) Recognition of performance - The desire to get a higher wage than usual and (v) Challenging work The desire to learn to masterwork in their field.

\subsection{Workload}

The workload is the volume of work results or records of work results that can show the volume produced by several employees in a certain section [14]. Also, workload defines as a condition of work with job descriptions that must be completed within a certain time limit [15]. Meanwhile, Jung \& Jung [16] define the workload as something that arises from the interaction between the demands of environmental tasks. Work where it is used as a workplace. In addition, Fritz \& Sonnentag [17] added that too much workload could cause tension in a person, causing stress. It could be due to the high level of expertise demanded, the work speed may be too high, the work volume may be too much and so on. Workload indicators are (i) Task Demands - namely, the workload, which can be determined from an analysis of the tasks performed by employees. However, individual differences are considered. (ii) Effort-The amount spent on a job may be a naturally intuitive form of workload. However, since there has been an increase in task 
demands, individuals may not be able to increase their level of effort and (iii) Performance-Most of the studies on workload are concerned with the performance to be achieved.

\subsection{Communication}

Communication is the process of conveying an idea from one person to another [18]. Also, Schement [19] added that communication is transmitting information, ideas, emotions, skills, and so on by using symbols- symbols, words, pictures, figures, graphics, etc. The act or process of transmission is what is commonly called communication. Meanwhile, Stern [20] added that communication occurs when a source delivers a message to the recipient with a conscious intention to influence the recipient's behaviour.

In addition, Elving [21] defines communication as the exchange of information between senders and receivers and conclude perceptions of the meaning of something between the individuals involved. Thus, communication is the process of delivering information from one party, be it individuals, groups or organizations, as a sender to another party as a receiver to understand, and there are opportunities to respond to the sender. Communication indicators to be effective include: Understanding, which is the ability to understand messages accurately as conveyed by the communicator. In this case, the communicant is said to be effective if he can understand correctly. Meanwhile, communicators are said to be effective if they convey the message carefully. Enjoyment, if the communication process is successful in conveying information, can also take place in a pleasant atmosphere for both parties. The purpose of communicating is not just a message transaction, but it is also intended for pleasant interaction to foster human relationships.

Effect on attitude: If a communicant receives a message, then his attitude changes according to the message's meaning. The act of influencing others is part of everyday life in an office. In many situations, we try to influence the attitudes of others and try to get others to be as positive as we want them to be. The relationship is getting better, which accidentally increases interpersonal relationships, and it will become effective communication. In offices, communication often occurs not to convey information or to influence attitudes alone, but sometimes there is an implicit intention, on the other hand, namely, to build good relationships.

\subsection{Performance}

Performance is an actual behaviour that each person displays as a work achievement produced by employees following their role in the company [22]. Another definition is also expressed by Gillet [23], which defines performance, which describes employees' work results following their role in the organization. According to Armstrong \& Baron [24], performance is defined as the result of work that has a strong relationship with the goals of organizational strategy, customer satisfaction and contributes to the economy. Thus, performance is about doing the job and the results achieved from that work. Performance contains meaning about what is done, how to do it and the work results.

According to Razak, Sarpan \& Ramlan [25], performance is the activities output in quality and quantity achieved by an employee in carrying out his duties by the responsibilities assigned to them. Meanwhile, according to Freeman [26], performance is the work that can be achieved by a person or group of people in an organization, according to their respective authority and responsibility, to legally accomplish the organization's objectives, not violating the organization's objectives law with morals and ethics. In addition, Koopmans, Bernaards, Hildebrandt, de Vet \& van der Beek [27] added six indicators for measuring individual employee performance: quality, quantity, on-time, effectiveness, independence and work commitment.

\subsection{Research Framework}

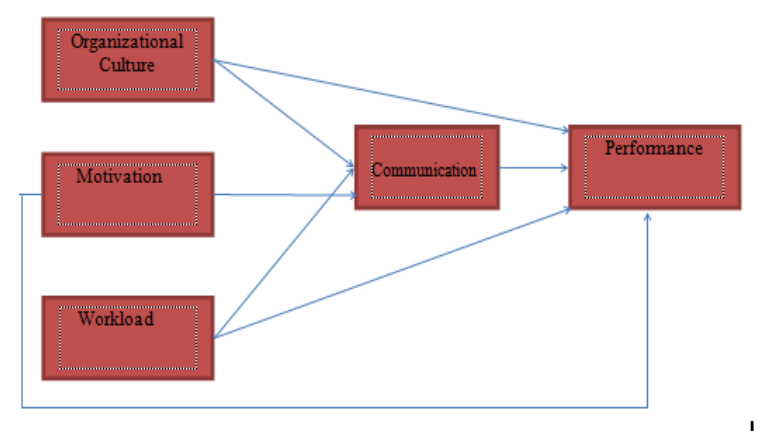

Fig. 1: Research Framework.

\subsection{Hypothesis}

Based on the research model above, the proposed hypotheses as follows:

H1: Organizational culture has a significant effect on employee performance.

H2: Motivation has a significant effect on employee performance.

H3: Workload has a significant effect on employee performance.

H4: Communication has a significant effect on employee performance. 
H5: Communication mediates the relationship between organizational culture and employee performance.

H6: Communication mediates the relationship between employee motivation and employee performance.

H7: Communication mediates the relationship between workload and employee performance.

\section{Research Methodology}

A population is a group of people, events, something that has certain characteristics [28]. It is an area of generalization that occurs from objects or subjects that become certain quantities and characteristics that researchers determine to study and draw conclusions, so the population is people and objects and other natural objects. The population is also not just the amount that will exist in the object or subject being studied but includes all the characteristics or properties of that subject or object. The population in this study amounted to 150 employees in the division of business development and Batam port management partnerships.

In general, a good sample can represent as many population characteristics as possible. The study sample used a census of 150 respondents of the Batam Port Management Partnership and Business Development Division. The primary data were collected by distributing the questionnaire through a census approach. The data were analyzed with structural equation modelling - partial least square (SEM-PLS).

\section{Results and Findings}

\subsection{Demography}

Batam Port Management Agency is a port operator in the free trade area and free port of Batam according to a joint decree of Transportation and the Head of the Batam Free Trade and Free Port Management Agency Number: KP 994 of 2017 and Number: 1456 / SPJ / KA / 11/2017, managed by the Batam Authority (Batam Concession Agency). It intended to achieve the goal of making Batam one of the locomotives of national development. The legal principle for the operation of Batam port is attached to one of the main tasks of the Batam Authority (BP Batam), which Presidential Decree mandates No. 41 of 1973 which can be chronologically described as follows: In 1971, the island of Batam was designated by the Central
Government as a private industrial area with Presidential Decree No. 74 of 1971 to facilitate Pertamina's logistical and operational base activities.

In accordance with the strong commitment of the government to advance Batam Island as an industrial and trading area, the Presidential Decree No. 41 of 1973, which was last amended to Presidential Decree No. 113 of 2000, mandates 5 main tasks to the Batam Authority, i.e., to plan, develop and control the development of Batam Island as an industrial area. Transhipment activities on the island of Batam. The need for infrastructure and operation of infrastructure installations. Examining business license applications, submitting them to the relevant agencies, and ensuring that licensing procedures run smoothly to foster investment interest.

\subsection{Measurement Model}

As mentioned previously, we use SEM-PLS to achieve the proposed objectives and hypotheses. Before embarking on the structural model, in the first step, we conducted the measurement model. The measurement model consists of loading factor, validity (convergence validity-Average Variance Extracted) and reliability (Cronbach Alpha, Rho_A, Composite reliability). The result of the measurement model by using the PLS Algorithm technique, as seen in Figure 2 below:

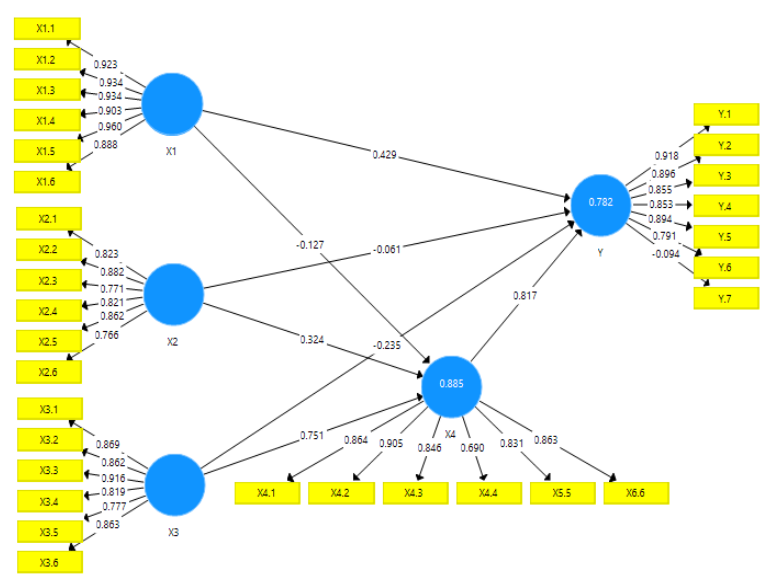

Fig. 2: The result of the measurement model by using the PLS Algorithm technique

\subsection{Validity and Reliability}

Internal consistency is an analysis to assess the validity of items, and the reliability of measurements are used. This study uses Cronbach Alpha, Rho_A and Composite reliability to identify whether the items are valid and measurements are reliable. In addition, we utilize the convergence validity by using Average Variance Extracted 
(AVE), it aims to assess the discriminant validity based on the following "rule of thumb": the positive square root of the AVE for each of the latent variables should be higher than the highest correlation with any other latent variable

The criteria for good construct reliability according to [29] can be seen from the value of composite reliability $>0.60$ and AVE $>0.50[30]$.

Table 1. The Result of Validity and Reliability

\begin{tabular}{|l|c|c|c|c|}
\hline \multicolumn{1}{|c|}{ Variable } & CA & Rho_A & CR & AVE \\
\hline Organizational Culture & 0.965 & 0.966 & 0.972 & 0.853 \\
\hline Motivation & 0.904 & 0.912 & 0.926 & 0.676 \\
\hline Workload & 0.924 & 0.926 & 0.941 & 0.726 \\
\hline Communication & 0.912 & 0.919 & 0.932 & 0.698 \\
\hline Performance & 0.865 & 0.940 & 0.914 & 0.648 \\
\hline
\end{tabular}

Note: CA (Cronbach's Alpha), Composite Reliability (CR) and AVE (Average Variance Extracted)

Table 1 shows the result of validity and reliability testing. The Organizational Culture variable has a composite reliability value of $0.972>$ 0.600 . Then, motivation has a composite reliability value of $0.926>0.600$. Workload has a composite reliability value of $0.941>0.600$. Communication has a composite reliability value of $0.932>0.600$ and Performance has composite reliability value of $0.914>0.600$. Thus, it can be concluded that all variables involved are valid and reliable.

\subsection{Structural Model}

The structural model can be assessed by using coefficient determination (R-square). R-Squares values can be used to explain the effect of exogenous latent variables on whether endogenous latent variables have substantive effects. R-Squares values of $0.75,0.50$, and 0.25 reflect that the model is strong, moderate, and weak. The following results of the R-The R-Square values, as seen in Table 2 below:

Table 2. The result of the coefficient determination (R-Square) and Effect Size (f-Square)

\begin{tabular}{|c|c|c|}
\hline Variable & R-Square & f-Square \\
\hline Communication & 0.885 & \multirow{2}{*}{0.895} \\
\hline Performance & 0.782 & \\
\hline
\end{tabular}

Table 2 shows the result of coefficient determination using (R-Square). The table above depicted that the organizational culture, motivation, workload, and communication can be explained by employee's performance as much as $78.2 \%$. In comparison, other variables explain the remaining
$21.8 \%$ are not included in this model. Whereas communication produces the R-square value is 0.885 , communication explains the organizational culture, motivation, workload at $88.5 \%$ and the remaining $11.5 \%$ is explained by other variables not considered in this model. Also, Cohen [31] provided the power table and sample size calculation based on the table in the PLS book. He looked at effect sizes (small, large, medium). From the result of analysis for $\mathrm{f}$-square, we can conclude that the effect size categorized as large.

\subsection{Hypothesis Testing}

Hypothesis testing is done through the bootstrapping process with Smart PLS. Hypothesis testing is accepted when using probability (P-Values) $<0.05$. The results of the bootstrapping process with SmartPLS, as seen in Table 3:

Table 3. Hypothesis Testing (Direct Effect)

\begin{tabular}{|l|c|c|c|}
\hline \multicolumn{1}{|c|}{ Variable } & Coefficient & T-Stat & P-Values \\
\hline ORC & 0.429 & 2.946 & 0.003 \\
\hline EMT & -0.061 & 0.310 & 0.757 \\
\hline WLD & -0.235 & 0.957 & 0.339 \\
\hline COM & 0.817 & 3.461 & 0.001 \\
\hline
\end{tabular}

Dependent variable: EPR (Employee Performance)

Note: ORC (Organizational Culture), EMT (Employee Motivation), WLD (Workload), COM (Communication)

Table 3 shows the Organizational Culture with Performance has a $\mathrm{P}$ value of $0.003<0.05$ with a statistic of 2.946> 1.96. The organizational culture has a significant direct influence on the performance of employees of the Batam Port Management Business Development and Partnership Section. Motivation with performance has a $\mathrm{P}$ value of $0.757>0.05$ with a statistic of $0.310>1.96$. Motivation has a direct and insignificant influence on the performance of employees of the Batam Port Management Business Development and Partnership Section.

Workload with performance has a $\mathrm{P}$ value of $0.339>0.05$ with a statistic of $0.957>1.96$. Then the workload has a direct and insignificant influence on the performance of employees of the Batam Port Management Partnership and Business Development Section and Communication with Performance has a $\mathrm{P}$ value of $0.001<0.05$ with a statistic of 3.461> 1.96, so communication has a significant direct influence on the performance of employees of the Batam Port Management Business Development and Partnership Section 
Table 4. Hypothesis Testing (Indirect Effect)

\begin{tabular}{|l|c|c|c|}
\hline \multicolumn{1}{|c|}{ Variable } & Coefficient & T-Stat & P-Values \\
\hline $\begin{array}{l}\mathrm{ORC} \rightarrow \mathrm{COM} \rightarrow \\
\mathrm{EPR}\end{array}$ & -0.104 & 0.858 & 0.391 \\
\hline $\begin{array}{l}\mathrm{EMT} \rightarrow \mathrm{COM} \rightarrow \\
\mathrm{EPR}\end{array}$ & 0.265 & 1.565 & 0.118 \\
\hline $\begin{array}{l}\mathrm{WLD} \rightarrow \mathrm{COM} \rightarrow \\
\mathrm{EPR}\end{array}$ & 0.614 & 3.443 & 0.001 \\
\hline
\end{tabular}

Dependent variable: EPR (Employee Performance)

Note: ORC (Organizational Culture), EMT (Employee Motivation), WLD (Workload), COM (Communication)

Table 4 displays the result of hypothesis testing for the indirect effect or mediating test. Communication does not mediate the relationship between organizational culture and employee performance with the value of regression coefficient is $-0.104, \mathrm{t}$-stat is 0.858 , and P-value is 0.391 or > 0.05 . Then, the communication does not mediate the relationship between employee motivation and employee performance with the value of regression coefficient is 0.265 , $\mathrm{t}$-stat is 1.565 , and P-value is 0.118 or $>0.05$. Besides that, communication mediates the relationship between workload and employee performance with the value of regression coefficient is 0.614 , t-stat is 3.443 , and P-value is 0.001 or $<0.01$. It means that increasing 1 percent in communication would mediate the relationship between workload and employee performance in Batam Port Management Partnership and Business Development Division as much as 61.4 percent.

\section{Conclusions and Suggestions}

\subsection{Conclusion}

Based on the study results, organizational culture and communication have a significant positive relationship with employee performance. Besides that, Motivation and Workload do not have a significant effect on employee performance. In addition, communication mediates the relationship between workload and employee performance. In conclusion, the present study proved that communication is a significant factor in determining employee performance and plays a significant role as mediating variable between workload and employee performance. This study contributes significantly to the theory and government policy in the term of human resource development. The findings of this study can assist the Batam Port Management Partnership and Business Development in increasing their employee performance through communication.

\subsection{Suggestion}

The organizational culture in the Batam Port Management Partnership and Business Development Division is good. The credibility and reputation of a leader to be able to provide inspiration and motivation to subordinates for performance in facing changes and developments in the world of work, motivation needs to be increased by providing rewards for outstanding employees, always maintaining friendship between leaders and subordinates, strengthening the kinship of fellow employees, understanding and recognizing deficiencies and the advantages of each employee, scheduling training for employees regularly and periodically.

\section{Acknowledgements:}

We would like to thank Universitas Syiah Kuala and Universiti Malaysia Terengganu for supporting this research publication and one form of research collaboration with the Universitas Syiah Kuala, Banda Aceh, Indonesia.

\section{References:}

[1] Inglis, D., Culture and everyday life. Routledge, 2004.

[2] Schwartz, S. H., "A theory of cultural values and some implications for work.," Appl. Psychol., vol. 48, no. 1, pp. 2-47, 1999.

[3] Cheney, G., Christensen, L. T., Zorn Jr, T. E., \& Ganesh, S., Organizational communication in an age of globalization: Issues, reflections, practices. Waveland Press, 2010.

[4] Burton, R. M., Obel, B., \& Håkonsson, D. D., Organizational Design. Cambridge University Press, 2020.

[5] Chia, R., Organizational analysis as deconstructive practice. Walter de Gruyter, 2014.

[6] Lok, P., \& Crawford, J., "The effect of organizational culture and leadership style on job satisfaction and organizational commitment: A cross-national comparison," J. Manag. Dev., vol. 23, no. 4, pp. 321-338, 2004.

[7] Ibrahim, R. Z. A. R., Saputra, J., Bakar, A. A., Dagang, M. M., Nazilah, S., Ali, M., \& Yasin, M. A. S. M., "Role of supply chain management on the job control and social support for relationship between work-family conflict and job satisfaction.," Int. J. Supply Chain Manag., vol. 8, no. 4, pp. 907-913, 
2019.

[8] Ginanjar, I. R., Hurriyati, R., Adiwibowo, L., Gaffar, V., \& Saputra, J., "The Role of Supply Chain Management Consumer Attitude as Intervening between Brand Images, Perceived Value and Revisiting Intention," Int. J. Supply Chain Manag., vol. 8, no. 4, pp. 901-906, 2019.

[9] Tesluk, P. E., Farr, J. L., \& Klein, S. R., "Influences of organizational culture and climate on individual creativity," J. Creat. Behav., vol. 31, no. 1, pp. 27-41, 1997.

[10] Ibrahim, R. Z. A. R., Saputra, J., Ali, S. N. M., Dagang, M. M., \& Bakar, A. A., "Organizational justice and job satisfaction among Malaysian workers," Opcion, vol. 35, no. 89, pp. 494-513, 2019.

[11] AbdiMohamud, S., Ibrahim, A. A., \& Hussein, J. M., "The effect of motivation on employee performance: Case study in Hormuud company in Mogadishu Somalia," Int. J. Dev. Res., vol. 9, no. 11, pp. 1700917016, 2017, doi: 10.5296/ijhrs.v5i2.7504.

[12] Andriani, S., Kesumawati, N., \& Kristiawan, M., "The influence of the transformational leadership and work motivation on teachers performance," Int. J. Sci. Technol. Res., vol. 7, no. 7, pp. 19-29, 2018.

[13] Urošević, S., Milijić, N., ĐorđevićMaljković, N., \& Karabašević, D., "Indicators of motivation and employee satisfaction in public enterprise: Case study of PE'Post of Serbia," Industrija, vol. 44, no. 3, pp. 77-95, 2016.

[14] Bruggen, A., "An empirical investigation of the relationship between workload and performance," Manag. Decis., vol. 53, no. 10, pp. 2377-2389, 2015.

[15] Bowling, N. A., \& Kirkendall, C., "Workload: A review of causes, consequences, and potential interventions.," Contemp. Occup. Heal. Psychol. Glob. Perspect. Res. Pract., vol. 2, pp. 221-238, 2012.

[16] Jung, H. S., \& Jung, H. S., "Establishment of overall workload assessment technique for various tasks and workplaces.," Int. J. Ind. Ergon., vol. 28, no. 6, pp. 341-353, 2001.

[17] Fritz, C., \& Sonnentag, S., "Recovery, wellbeing, and performance-related outcomes: The role of workload and vacation experiences.," J. Appl. Psychol., vol. 91, no. 4, p. 936, 2006.

[18] Lunenburg, F. C., "Communication: The process, barriers, and improving effectiveness," Schooling, vol. 1, no. 1, pp. $1-10,2010$.

[19] Schement, J. R., "Communication and information," in Between Communication and Information, Routledge, 2017, pp. 3-33.

[20] Stern, B. B., "A revised communication model for advertising: Multiple dimensions of the source, the message, and the recipient," J. Advert., vol. 23, no. 2, pp. 515, 1994.

[21] Elving, W. J., "The role of communication in organizational change.," Corp. Commun. An Int. J., vol. 10, no. 2, pp. 129-138, 2005.

[22] Nguyen, P. T., Yandi, A., \& Mahaputra, M. R., "Factors That Influence Employee Performance: Motivation, Leadership, Environment, Culture Organization, Work Achievement, Competence And Compensation (A Study Of Human Resource Management Literature Studies)," Dinasti Int. J. Digit. Bus. Manag., vol. 1, no. 4, pp. 645-662, 2020.

[23] Gillet, N., Colombat, P., Michinov, E., Pronost, A. M., \& Fouquereau, E., "Procedural justice, supervisor autonomy support, work satisfaction, organizational identification and job performance: The mediating role of need satisfaction and perceived organizational support.," ournal Adv. Nurs., vol. 69, no. 11, pp. 2560-2571, 2013.

[24] Armstrong, M., \& Baron, A., Strategic HRM: The key to improved business performance. CIPD Publishing., 2002.

[25] Razak, A., Sarpan, S., \& Ramlan, R., Effect of leadership style, motivation and work discipline on employee performance in PT. ABC Makassar," Int. Rev. Manag. Mark., vol. 8, no. 6, p. 67, 2018.

[26] Freeman, R. M., "Correctional organization and management," in Public policy challenges, behavior, and structure, Elsevier, 1999.

[27] Koopmans, L., Bernaards, C. M., Hildebrandt, V. H., de Vet, H. C., \& van der Beek, A. J., "Measuring individual work performance: Identifying and selecting indicators," Works, vol. 48, no. 2, pp. 229238, 2014.

[28] Yanti, S., Haluddin, R., Rumengan, J., \& Maniah, M., "The Effect of Competency, Motivation of Work Training on the Work Achievement of Employees Classification Indonesia Bureau of Batam Branch," INOBIS J. Inov. Bisnis dan Manaj. Indones., vol. 3, 
no. 3, pp. 354-362, 2020.

[29] Rg Henseler, J., Dijkstra, T. K., Sarstedt, M., Ringle, C. M., Diamantopoulos, A., Straub, D. W., ... \& Hult, M., "Point/Counterpoint on Partial Least Squares Common Beliefs and Reality About PLS: Comments on Rö nkkö and Evermann (2013)," Organ. Res. Methods, vol. 17, no. 2, pp. 182-209, 2014, doi: 10.1177/1094428114526928.

[30] Black, W., \& Babin, B. J., "Multivariate data analysis: Its approach, evolution, and impact.," in In The Great Facilitator, Springer, Cham., 2019, pp. 121-130.

[31] Cohen, J., "A power primer," Psychol. Bull., vol. 112, no. 2, p. 155, 1992.
Contribution of Individual Authors to the Creation of a Scientific Article (Ghostwriting Policy)

-Mahdani Ibrahim writing - original draft, investigation, editing and supervision.

-Jumadil Saputra writing - methodology, review, editing, investigation, and data analysis.

-Muhammad Adam methodology, review, and editing.

-Mukhlis Yunus writing - methodology, review, and editing.

Creative Commons Attribution License 4.0 (Attribution 4.0 International, CC BY 4.0)

This article is published under the terms of the Creative Commons Attribution License 4.0

https://creativecommons.org/licenses/by/4.0/deed.en US 